\title{
Korean Learners' Acquisition and Use of Variable First-Person Subject Forms in Spanish
}

\begin{abstract}
Avizia Y. Long (D)
Department of World Languages and Literatures, San José State University, San Jose, CA 95192, USA; avizia.long@sjsu.edu

Abstract: Within the scope of research that lies at the intersection of sociolinguistics and second language acquisition, there is a growing body of empirical work on learners' acquisition of variable subject expression in Spanish. This research has been instrumental for demonstrating that second language (L2) learners acquire linguistic and social constraints on subject form use. The present study extends research on variable Spanish subject expression to an understudied learner population: native Korean-speaking learners. Interview data were examined for the range and frequency of first-person subject forms produced by Korean-speaking learners at four instructional levels as well as linguistic and individual (extralinguistic) predictors of subject use. Results showed that learners at each level produced primarily null subjects, and verb number, verb-form regularity, verb semantics, and use of Spanish outside of class significantly predicted use of an overt personal pronoun over null subjects.
\end{abstract}

Citation: Long, Avizia Y.. 2021.

Korean Learners' Acquisition and Use of Variable First-Person Subject Forms in Spanish. Languages 6: 208 https://doi.org/10.3390/

languages6040208

Academic Editor: Aarnes Gudmestad

Received: 16 June 2021

Accepted: 7 December 2021

Published: 13 December 2021

Publisher's Note: MDPI stays neutral with regard to jurisdictional claims in published maps and institutional affiliations.

Copyright: (c) 2021 by the author. Licensee MDPI, Basel, Switzerland. This article is an open access article distributed under the terms and conditions of the Creative Commons Attribution (CC BY) license (https:// creativecommons.org/licenses/by/ $4.0 /)$.
Keywords: subjects; Spanish; Korean learners; second language (L2)

\section{Introduction}

Within the scope of research that lies at the intersection of sociolinguistics and second language acquisition (e.g., Bayley and Preston 1996; Geeslin and Long 2014; Regan and Bayley 2004), there is a growing body of empirical literature that focuses on learners' development and use of variable morphosyntactic phenomena. The majority of these studies have examined sociolinguistic variation in second- language (L2) French or Spanish and contribute to theoretical discussions on learners' developing sociolinguistic competence, or the ability to use language in linguistically and socially appropriate ways (Canale and Swain 1980).

The present study examines Korean learners' acquisition and use of variable subject forms in Spanish. Variationist research on subject expression in L2 Spanish has investigated learners' sensitivity to linguistic factors known to constrain the alternation between selection or omission of subject forms in native Spanish (e.g., Geeslin and Gudmestad 2008b, 2016; Geeslin et al. 2015; Gudmestad and Geeslin 2010; Gudmestad et al. 2013), thereby contributing broadly to the study of sociolinguistic competence in L2 Spanish. This research has focused nearly exclusively on English-speaking learners, whose first language does not permit subject omission with tensed verbs. Research on Korean learners of Spanish, whose first language permits subject omission, has begun to receive attention (e.g., Long 2016; see also Long and Geeslin 2018), and the present study builds on it by exploring the role of individual learner characteristics in the acquisition of variable subject expression in L2 Spanish.

Following a comparison of subject expression in Spanish and Korean, this article provides a brief review of previous research on the L2 acquisition of Spanish subject expression to highlight key findings reported for native English-speaking learners. The methodology is then summarized, followed by presentation and discussion of the results. 


\section{Background}

\subsection{Comparison of Spanish and Korean Subject Expression}

Both Spanish and Korean are pronoun-dropping, or pro-drop, languages. However, each language differs notably with respect to how subjects are expressed or used.

Spanish subjects may be expressed overtly as personal pronouns, lexical noun phrases, and other types of less frequently occurring pronouns. The Spanish language also permits null subjects whereby the referent of a tensed verb is not explicitly expressed. The different subject forms permitted in Spanish are illustrated in (1).

(1) Es profesora (null subject)

"[He/she] is a professor"

Los estudiantes son listos (lexical noun phrase)

"The students are bright"

Ellos también son trabajadores (personal pronoun)

"They are also hard working"

Esto es diferente (demonstrative pronoun)

"This is different"

¿Quién es? (interrogative pronoun)

"Who is it?"

Alguien no era muy responsable (indefinite pronoun)

"Someone wasn't very responsible"

In most finite contexts (i.e., subject + tensed verb), Spanish subjects are variably realized with either an overt form or as a null subject, as shown in (2). Subject dropping in Spanish varies across dialects, ranging from as little as 20\% (Madrid: Cameron 1992) to as much as 50\% or higher (Santo Domingo: Martínez-Sanz 2011). This syntactic context is of interest in the present study and has been the focus of extensive theoretical and empirical attention in the sociolinguistics and second language acquisition literature.

(2) Yo quiero eso

"I want that"

$\varnothing$ Quiero eso

"[I] want that"

Research in the field of sociolinguistics in particular has been instrumental in identifying the factors that constrain or influence this variation between overt and null subject forms in native-speaker Spanish, and most previous studies have limited their analysis to null subjects and overt subject pronouns (although see, e.g., Dumont 2006; Gudmestad et al. 2013; Gudmestad and Geeslin 2021, who include lexical noun phrases in their analyses of third-person subject expression). The linguistic factors selected for examination pertain to aspects of the linguistic system as well as the discourse-pragmatic context in which speakers communicate. Table 1 offers a summary of key linguistic factors that have been examined in previous research on variable subject expression in Spanish, as well as findings from studies that have investigated those factors ${ }^{1}$. These factors have been key to explaining patterns of subject expression across varieties of native-speaker Spanish (Carvalho et al. 2015), as well as non-native or L2 Spanish (e.g., Geeslin et al. 2015; Geeslin and Gudmestad 2008b). With respect to the factors of verb person and verb number, it is important to highlight that some studies have analyzed verb persons separately (e.g., first-person vs. third-person subjects), given the differing range of variants observed across distinct verb person and number contexts, and because research has found it to be one of the most important predictive factors (e.g., de Prada Pérez 2015; Geeslin and Gudmestad 2016; Gudmestad and Edmonds n.d.; Posio 2011; Torres Cacoullos and Travis 2010). Given these differences, the present study focused exclusively on first-person subjects. 
Table 1. Linguistic factors examined in previous research on variable subject expression.

\begin{tabular}{|c|c|}
\hline Factor & Findings \\
\hline Verb number & $\begin{array}{l}\text { Overt subject forms are more frequent with } \\
\text { singular than plural referents (e.g.; } \\
\text { Ávila-Jiménez 1995; Bayley and Pease-Álvarez } \\
\text { 1997; Cameron 1993; Enríquez 1984; } \\
\text { Flores-Ferrán 2004; Hochberg 1986; Holmquist } \\
\text { 2012; Morales 1986; Otheguy and Zentella 2012) }\end{array}$ \\
\hline Verb person & $\begin{array}{l}\text { Overt subject forms are more frequent with } \\
\text { first-person than third-person singular verbs } \\
\text { (e.g., Abreu 2009, 2012; Bayley and } \\
\text { Pease-Álvarez 1997; Cameron 1993; } \\
\text { Flores-Ferrán 2004; Geeslin and Gudmestad } \\
\text { 2008b; Holmquist 2012) }\end{array}$ \\
\hline Verb-form ambiguity & $\begin{array}{l}\text { Overt subject forms are more frequent with } \\
\text { potentially ambiguous verb forms (e.g., } \\
\text { Hochberg 1986; Silva-Corvalán 1982) }\end{array}$ \\
\hline Verb-form regularity & $\begin{array}{l}\text { Overt subject pronouns occur more frequently } \\
\text { for morphologically regular verbs than for } \\
\text { irregular verbs (Erker and Guy 2012) }\end{array}$ \\
\hline Verb tense-mood-aspect (TMA) & $\begin{array}{l}\text { Overt subject forms are more frequent with } \\
\text { imperfect, subjunctive, and conditional verb } \\
\text { forms (e.g., Abreu 2009; Bayley and } \\
\text { Pease-Alvarez 1997; Travis 2005) }\end{array}$ \\
\hline Verb semantics & $\begin{array}{l}\text { Overt subject forms occur more frequently with } \\
\text { mental activity or psychological verbs such as } \\
\text { pensar "to think" and creer "to believe" (e.g., } \\
\text { Bayley et al. 2013; Erker and Guy 2012; } \\
\text { Travis 2005, 2007) }\end{array}$ \\
\hline Switch reference & $\begin{array}{l}\text { Overt subject forms are more frequent in switch } \\
\text { reference contexts (e.g., Ávila-Jiménez 1995; } \\
\text { Bayley and Pease-Álvarez 1997; Cameron 1992, } \\
\text { 1993; Flores-Ferrán 2002, 2004; Morales 1986; } \\
\text { Silva-Corvalán 1982; Shin and Otheguy 2009) }\end{array}$ \\
\hline Priming & $\begin{array}{l}\text { Expressed subjects (i.e., overt forms) follow } \\
\text { previously expressed subjects (e.g., Abreu 2012; } \\
\text { Cameron 1994; Cameron and Flores-Ferrán 2004; } \\
\text { Travis 2005) }\end{array}$ \\
\hline
\end{tabular}

Although both Spanish and Korean are pro-drop languages, Korean differs from Spanish in that its word order is subject-object-verb (as opposed to subject-verb-object for Spanish), and objects along with subjects may be dropped when pragmatically appropriate (Sohn 1999). With respect to subject expression, Korean permits a variety of forms in subject position, including null subjects (which Spanish also permits), as illustrated in (3). 




$\begin{array}{lll}\text { Some person } & \text { book-ACC lose-PST-DECL } \\ \text { "Someone lost the book" } & \end{array}$

ilheo beol-yeoss-da (indefinite pronoun)

Subject dropping is fairly common in spoken and written Korean (nearly $70 \%$ in spoken language and about 50\% in written language; Kim 2000; see also Lee 2019). According to Sohn (1999), this is particularly the case when the subject refers to the speaker in declarative sentences (e.g., danyeo wasseo "[I] am back") and the hearer in interrogative sentences (e.g., da haesseo? "Are [you] all done?"). In some contexts, such as greeting, thanking, apologizing, and congratulating, subjects do not appear and may be considered ungrammatical or unacceptable if used explicitly (Sohn 1999).

Korean also differs from Spanish in that it has a system of hierarchical personal pronouns for first- and second-person subject referents (see Table 2). With respect to firstperson subject pronouns, the plain or informal forms are generally used when speaking with children or younger adults, whereas the humble or polite forms are used when speaking with someone senior or a social equal. Second-person subject pronouns are not used to refer to addressees who occupy a higher social position than the speaker; speakers instead use nominals such as professional titles to refer to socially superior individuals (e.g., seonsaeng-nim "esteemed teacher," sajang-nim "esteemed company president; Sohn 1999 , p. 409). Speakers may also use a kinship term (e.g., oppa "brother [female speaker]," halmeoni "grandmother") or a name to refer to their addressees. That stated, speakers' selection and use of a reference form (particularly for second-person referents) are not fixed (Na 1988) and depend on a complex and dynamic interplay of social factors such as age, closeness, and discourse formality (Lee 2019). 
Table 2. Korean personal pronouns (see Sohn 1999, p. 207).

\begin{tabular}{|c|c|c|}
\hline Person & Singular & Plural \\
\hline First & $\begin{array}{c}\text { na } \\
\text { "I (plain)” } \\
\text { jeo } \\
\text { “I (humble)" }\end{array}$ & $\begin{array}{c}\text { uli } \\
\text { "we (plain)" } \\
\text { jeohui } \\
\text { "we (humble)" }\end{array}$ \\
\hline Second & $\begin{array}{c}\text { neo } \\
\text { "you (plain)" } \\
\text { jane } \\
\text { "you (familiar)" } \\
\text { dangshin } \\
\text { "you (blunt)" }\end{array}$ & $\begin{array}{c}\text { neohui-dul } \\
\text { “you all (plain)" } \\
\text { jane-dul } \\
\text { “you all (familiar)" } \\
\text { dangshin-dul } \\
\text { "you all (blunt)" }\end{array}$ \\
\hline
\end{tabular}

Third-person personal pronouns such as he, she, and they that are common in Indo European languages do not have an exact equivalent in Korean. Instead, the demonstrative geu is used or combined with other morphemes to refer to individuals in the third person: geu "he, it," geu-nyeo "she," geu-deul "they." Demonstrative pronouns are used to refer to objects in contexts of third-person reference (igeot "this," geugeot "that," jeogeot "that over there").

Subject dropping in Korean has garnered extensive attention in previous research (e.g., Ahn and Kwon 2012; Huang 1984, 1989; Im 1985; Lee 1993; Moon 2010), perhaps due to the prevalence of this phenomenon in spoken discourse (Lee 2019). Fewer studies focus on overtly expressed subjects and do so from a pragmatic perspective as opposed to a formal syntactic perspective. To date the most comprehensive analysis of overt subject expression in Korean from a pragmatic point of view has been carried out by Lee (2019), who focused on first- and second-person subjects in spoken Korean. Her quantitative analysis showed that overt expression was infrequent (31\% for first-person referents and $22 \%$ for second-person referents) and patterned distinctly by age and gender differences. Specifically, male speakers employed more first-person subjects with other male speakers than female speakers; male speakers also used more first-person subjects with younger speakers than older or same-aged speakers. Female speakers, on the other hand, employed first-person subjects at similar rates regardless of any age or gender differences. For secondperson subjects, overt expression was more frequent with peers than younger or older speakers for both male and female speakers. N. Lee's discourse analysis revealed that overt expression occurred when speakers created explicit or implicit contrast between referents (e.g., "I am going to the office today, but Mr. Murata is not" [explicit contrast; p. 112]; "Do [you] remember? You ran away in front of the gate to the court" [implicit contrast). To the best of the author's knowledge, a quantitative, variationist account of subject expression in Korean does not exist.

In sum, although both Spanish and Korean permit null subjects, each language differs with respect to the factors or constraints guiding subject omission. Furthermore, the range of subject forms used by speakers to address themselves, their listener(s), and others is distinct and does not share the same contexts of use across these languages, which is likely due to the hierarchical system of personal pronouns for first- and second-person referents and the lack of true personal pronouns for third-person referents in Korean. Based on these observations and keeping in mind that the current study focuses on first-person referents, the primary acquisitional challenge facing Korean-speaking learners in the development and use of variable first-person subject expression in Spanish includes adjusting rates of null subject use to reflect sensitivity to linguistic factors known to influence variable subject omission in native-speaker Spanish.

\subsection{L2 Acquisition of Spanish Subject Expression}

The development and use of Spanish subjects have garnered extensive attention in the L2 acquisition literature. Previous research on subject expression in L2 Spanish 
has been examined from a variety of theoretical perspectives, including generative (e.g., Al-Kasey and Pérez-Leroux 1998; Isabelli 2004; Liceras and Díaz 1998, 1999; Lozano 2002a, 2002b; Pérez-Leroux and Glass 1997, 1999; Rothman and Iverson 2007a, 2007b, 2007c), discourse-pragmatic (e.g., Blackwell and Quesada 2012; Quesada and Blackwell 2009), and variationist (e.g., Geeslin and Gudmestad 2008b, 2011, 2016; Gudmestad and Geeslin 2010; Gudmestad et al. 2013; Linford 2009, 2012). The review presented in this section will focus on previous research carried out from a variationist perspective, as the present study adopted this framework for examining variable subject expression in L2 Spanish.

Variationist research on subject expression in L2 Spanish has aimed to document patterns of subject expression in learner Spanish, focusing on native English-speaking learners (e.g., Geeslin and Gudmestad 2008b, 2011, 2016; Gudmestad and Geeslin 2010). This body of research adopted methodologies from quantitative sociolinguistics (Labov 1972; Tagliamonte 2012) and incorporated a native-speaker comparison group in their analyses to determine whether learners' patterns of use demonstrate sensitivity to the same linguistic and extralinguistic factors or constraints observed for native speakers. For example, Geeslin and Gudmestad (2008b) demonstrated that advanced learners produced the same range of subject forms as native speakers during a sociolinguistic interview. Subtle differences in frequencies for some subject types were uncovered, particularly when examined against verb person, number and specificity of the referent. Specifically, the advanced learners used more null subjects than native speakers with first-person plural, second-person singular, and third-person singular referents. Additionally, the distribution of subject forms with group and non-specific referents differed between learner and nativespeaker groups.

In a follow-up study, Gudmestad and Geeslin (2010) extended their analysis of advanced learners' use of Spanish subjects to include verb TMA, another linguistic factor examined extensively in variationist research on subject expression in native-speaker Spanish, as well as verb form ambiguity and switch reference. They found that the distribution of subject forms produced by learners and native speakers differed significantly across categories of the verb TMA factor, and the effect of this factor was mediated by discourse redundancy. Specifically, verb TMA effects persisted in switch but not same-reference contexts. Geeslin and Gudmestad further explored the role of discourse on advanced learner subject expression in their 2011 study that focused on two discourse-level factors: referent cohesiveness and perseveration (i.e., priming). Referent cohesiveness refers to "the distance and function of the previous mention of the referent" (Geeslin and Gudmestad 2011, p. 21). They found that subject expression was influenced by distance from the original mention of the referent, in that fewer null subjects were produced as distance increased. With respect to the perseveration variable, both learners and native speakers demonstrated the pattern for more null subjects following null subjects and more overt subjects following overt subjects.

In his cross-sectional study on native English-speaking learners of Spanish, Linford (2009) examined the relationship between L2 learners' subject expression and several linguistic factors including verb person and number, referent specificity, continuity of reference (i.e., switch reference), verb semantics, clause type, as well as extralinguistic factors such as age, gender, and time spent abroad. With respect to rates of subject use, Linford found that beginning learners produced primarily null subjects $(60.1 \%)$ and the rate of null subject use increased as proficiency increased (reaching $87.4 \%$ for advanced learners). Linford noted that these rates overshot native-speaker rates (Otheguy et al. 2007), an observation that is echoed in variationist L2 research on subject expression (see also Geeslin et al. 2015). With regard to the linguistic factors examined, learners' use of subject forms showed more similarities with than differences from native speakers. For instance, a higher rate of overt subjects was observed with singular as opposed to plural referents and in contexts of switch reference as opposed to same-reference contexts. Linford's analysis also uncovered an effect for speaker gender whereby female learners, similarly to female native speakers, produced overt subject pronouns at a higher rate than male learners. 
To summarize, previous research on L2 Spanish subject expression carried out within the variationist tradition has established several key findings. Firstly, learners produce the same range of subject forms as native speakers, and rates of subject form use show subtle differences from native speakers. Developmental research shows that English-speaking learners' use of null subjects increases as proficiency in the language increases, eventually overshooting native-speaker rates (Linford 2009). Secondly, learners demonstrate nativelike sensitivity to several of the linguistic factors that explain native-speaker use in the sociolinguistics literature, but again subtle differences between learners and native speakers are reported. The preceding review illustrates an exclusive focus on English-speaking learners, whose first language does not permit subject omission with tensed verbs, as well as a general lack of examination of individual characteristics such as speaker sex and experience with the Spanish language (for an exception, see Gudmestad and Edmonds n.d.) ${ }^{2}$. Research on Korean learners of Spanish, whose first language permits subject omission, has begun to receive attention (e.g., Long 2016; see also Long and Geeslin 2018), and the present study builds on it by exploring the role of individual learner characteristics in the acquisition of variable subject expression in L2 Spanish.

Given differences in Spanish subject expression across verb person and number contexts (see, e.g., de Prada Pérez 2015; Geeslin and Gudmestad 2016; Gudmestad and Edmonds n.d.; Posio 2011; Torres Cacoullos and Travis 2010), the present study focused narrowly on patterns of subject form use by Korean-speaking learners in contexts of first-person reference. The following research questions guided the present study:

1. What forms do Korean-speaking learners produce in the subject position of tensed verbs for first-person referents in Spanish?

2. With what frequency are first-person subject forms produced, and how does this frequency change across four different levels of instruction?

3. What linguistic and extralinguistic factors predict first-person subject form use for Korean-speaking learners of Spanish?

\section{Materials and Methods}

\subsection{Participants and Setting}

Interview data from Long's (2016) dataset of 66 Korean-speaking learners of Spanish (46 females, 20 males; average age 21 years) were examined for the present study. All learners reported Korean as their native language and the language spoken in their homes. Learner participants were recruited from Spanish language and content courses across four instructional levels offered at a private Korean university located in Gwangju. Justification for treating these levels as distinct groups representing increasing knowledge of and experience with the Spanish language (starting with the first year and ending with the fourth year) is elaborated in Long (2021a). Additional characteristics of the Korean-speaking learners of this study are provided in Table 3. Given that the overarching goal of the current study is to extend L2 research on variable subject expression to learners of an understudied first language, the results are considered primarily in light of previous research on English-speaking L2 learners of Spanish, rather than native speakers of Spanish.

Table 3. Characteristics of Korean-speaking learners.

\begin{tabular}{ccccc}
\hline $\begin{array}{c}\text { Instructional } \\
\text { Level }\end{array}$ & $\boldsymbol{n}$ & $\begin{array}{c}\text { Formal Instruction in } \\
\text { Spanish (Years) }\end{array}$ & $\begin{array}{c}\text { Average Spanish } \\
\text { Grammar Test Score } \\
\text { (Max. 25) }\end{array}$ & $\begin{array}{c}n \text { Study Abroad } \\
\text { Experience }\end{array}$ \\
\hline First year & 29 & $<1$ & $8.8(2.5)$ & 1 \\
Second year & 14 & $1-2$ & $10.6(2.7)$ & 2 \\
Third year & 14 & $2-3$ & $11.9(2.0)$ & 0 \\
Fourth year & 9 & $4-5$ & $14.6(3.7)$ & 4 \\
\hline
\end{tabular}

Note: Standard deviations are provided in parentheses. 


\subsection{Tasks and Procedure}

The Korean-speaking learners in Long (2016) participated in a 20-min interview in Spanish to elicit semi-spontaneous oral production data. This particular elicitation technique was selected following previous variationist research on Spanish subject expression (both native and L2). During the interview the researcher asked each learner the same set of questions to facilitate conversation on a variety of topics such as school, friends and family, future plans, and opinions about society and culture. Each interview was recorded and transcribed for coding and analysis as described in the next sections.

Immediately following the interview, each participant completed a 25-item Spanish grammar test and background questionnaire, respectively. The grammar test, used extensively in research on variation in L2 Spanish (see Geeslin and Gudmestad 2008a), measured knowledge of common lexical and morphosyntactic phenomena in the Spanish language. This task required learners to complete a short written narrative by selecting the form that best completed select phrases and sentences embedded in the story. The background questionnaire elicited demographic information from each participant and details surrounding their experience with Spanish and other languages. Data from the background questionnaire were used to examine individual characteristics of subject use.

\subsection{Coding and Analysis}

Each interview transcription was examined to identify all first-person contexts in which variable subject expression could occur (i.e., the variable context) and to code each variable context for the dependent variable (overt personal pronoun vs. null subject) as well as several independent factors that have been investigated to explain development and use by L2 learners in previous studies. Following previous research (e.g., Geeslin and Gudmestad 2016), the variable context was the subject form produced with any finite first-person verb form.

Each variable context constituted a token of analysis, and each token was coded for the subject form employed (the dependent variable) and several linguistic and extralinguistic factors (the independent variables). For the dependent variable, null subjects, overt personal pronouns, and lexical noun phrases (for plural referents, e.g., mi hermana y yo "my sister and I") were expected. The linguistic factors are listed and exemplified in Table 4. The extralinguistic factors selected for coding and analysis included speaker gender, use of Spanish outside of class (daily, weekly, monthly, yearly, and never), previous experience abroad in a Spanish-speaking country (yes or no), and course level (first, second, third, and fourth year). Various studies motivated the inclusion of these particular factors: Linford (2009), who reported a significant effect of speaker gender on English-speaking learners' use of overt subject pronouns, and Long (2021b), who reported positive correlations between variable copula use and two individual characteristics (use of Spanish outside of class and previous study abroad experience) for the fourth-year Korean-speaking learners of the present study. Various investigations of variable structures have also found evidence of differences according to instructional level (see Gudmestad 2012, for mood use).

Linear mixed modeling using the lme4 package (Bates et al. 2015) in R (R Core Team 2019) was used to assess the effect of linguistic and extralinguistic factors on subject form use. In addition to predicting subject form use, this statistical modeling technique permits the inclusion of random effects to account for hierarchical groupings in the data.

The full model considered each linguistic factor listed in Table 4 and four extralinguistic factors (course level, speaker gender, use of Spanish outside of class, and previous study abroad experience) as fixed effects, and speaker and verb as varying intercepts or random effects. The minimal adequate model, which included terms that were not systematically discarded during analysis (starting with terms with the highest $p$ value), is presented in the results section. 
Table 4. Summary of Coding for Linguistic Independent Factors.

\begin{tabular}{|c|c|c|}
\hline Factors & Levels & Example from Dataset \\
\hline Verb number & Singular & $\begin{array}{l}\text { primero me levanto y voy }[\ldots] \text { "first }[\mathrm{I}] \text { get up and } \\
{[\mathrm{I}] \text { go }[\ldots] \text { " }(\mathrm{P} 12, \text { Second year })}\end{array}$ \\
\hline \multirow{4}{*}{$\begin{array}{l}\text { Verb-form } \\
\text { regularity }\end{array}$} & Plural & $\begin{array}{l}\text { en Busan podemos comer mucho y ver... podemos } \\
\text { ver la vista "In Busan [we] can eat a lot and see ... } \\
\text { [we] can see the view" (P9, Third year) }\end{array}$ \\
\hline & Form specific & $\begin{array}{l}\text { su personalidad no sé "her personality [I] don't } \\
\text { know" (P32, First year) }\end{array}$ \\
\hline & Irregular & $\begin{array}{c}\text { quiero ser }[\ldots] \text { “ }[\mathrm{I}] \text { want to be }[\ldots] " \\
(\mathrm{P} 45, \text { Second year })\end{array}$ \\
\hline & Regular & $\begin{array}{c}\text { creo que más o menos "[I] think more or less" } \\
\text { (P1, Fourth year) }\end{array}$ \\
\hline \multirow[t]{3}{*}{ Verb semantics } & External activity & $\begin{array}{c}\text { primero me levanto y voy }[\ldots] \text { "first I get up and } \\
{[\mathrm{I}] \text { go }[\ldots] \text { " }}\end{array}$ \\
\hline & Mental activity & mm no sé "mm [I] don't know" (P19, Second year) \\
\hline & Stative & $\begin{array}{c}\text { soy interesante y ... amable " }[\mathrm{I}] \text { am interesting and } \\
\ldots \text {.. kind" (P32, First year) }\end{array}$ \\
\hline \multirow[t]{2}{*}{ Switch reference } & Same reference & $\begin{array}{c}\text { yo no sé exactamente pero pero uh yo quiero, yo quiero } \\
\text { azafata "I don't know exactly but uh I want flight } \\
\text { attendant" (P52, Second year) }\end{array}$ \\
\hline & Switch reference & $\begin{array}{c}\text { creo que uh algo de estudiante es más ... listo "[I] } \\
\text { think that uh something of student is more ... } \\
\text { intelligent" (P64, Third year) }\end{array}$ \\
\hline \multirow[t]{2}{*}{ Priming } & $\begin{array}{l}\text { Previous mention of } \\
\text { current referent is } \\
\text { expressed overtly }\end{array}$ & $\begin{array}{c}\text { primero uh yo quiero ser azafata ... segunda segundo } \\
\text { segundo ah yo quiero ser actora "first uh I want to be } \\
\text { flight attendant ... second ah I want to be actor" } \\
\text { (P36, Third year) }\end{array}$ \\
\hline & $\begin{array}{l}\text { Previous mention of } \\
\text { current referent is } \\
\text { null }\end{array}$ & $\begin{array}{c}{[\ldots] \text { y a las dos } \varnothing \text { tengo ... Ø tengo clase con }} \\
\text { Professor }{ }^{* * *} \text { y a las a las cuatro Ø tengo ... escuchar } \\
\text { "[...] and at } 2[\mathrm{I}] \text { have ... [I] have class with } \\
\text { Professor *** and at at } 4[\mathrm{I}] \text { have ... listening" } \\
\text { (P41, Second year) }\end{array}$ \\
\hline
\end{tabular}

a For a description of the categories of verb-form regularity, see Gudmestad (2012).

\section{Results}

\subsection{Overall Distribution of Subject Forms}

765 tokens were identified for analysis of subject-form use in first-person contexts. Table 5 presents the overall distribution of subject forms produced by Korean-speaking learners during the interview task. Null subjects accounted for the majority of subject forms produced by Korean-speaking learners in first-person contexts. The second most frequently used subject form was an overt personal pronoun (29\%). Lexical noun phrases, which are possible in plural contexts only, were very infrequently produced (1\%). However, only one instance of this form was appropriate in the dataset of the present study (pero uh mi amigos y yo uh tenemos un una plan "but my friends and I have a plan"). The remaining uses of lexical noun phrases in first-person contexts $(n=7)$ occurred with singular, first-person verb forms (e.g., mis amigos uh voy a empezar su trabajo "my friends uh [I] am going to start their jobs"). These tokens (along with all lexical noun phrases, $n=8$ total) were excluded from further inferential statistical analysis in the present study.

Table 5. Distribution of subject forms.

\begin{tabular}{ccc}
\hline Subject Form & Count & Percentage \\
\hline Null subject & 536 & 70 \\
Overt personal pronoun & 221 & 29 \\
Lexical noun phrase & 8 & 1 \\
\hline
\end{tabular}


Figure 1 presents the distribution of first-person subject forms produced by instructional level (first, second, third, and fourth year). Learners at each level produced primarily null and overt personal pronouns, and null subjects were observed at a much higher rate than overt personal pronouns with first-person verbs; this pattern was strongest for first-, second-, and third-year learners. Fourth-year learners produced overt personal pronouns at a notably higher rate that first, second, and third-year learners.

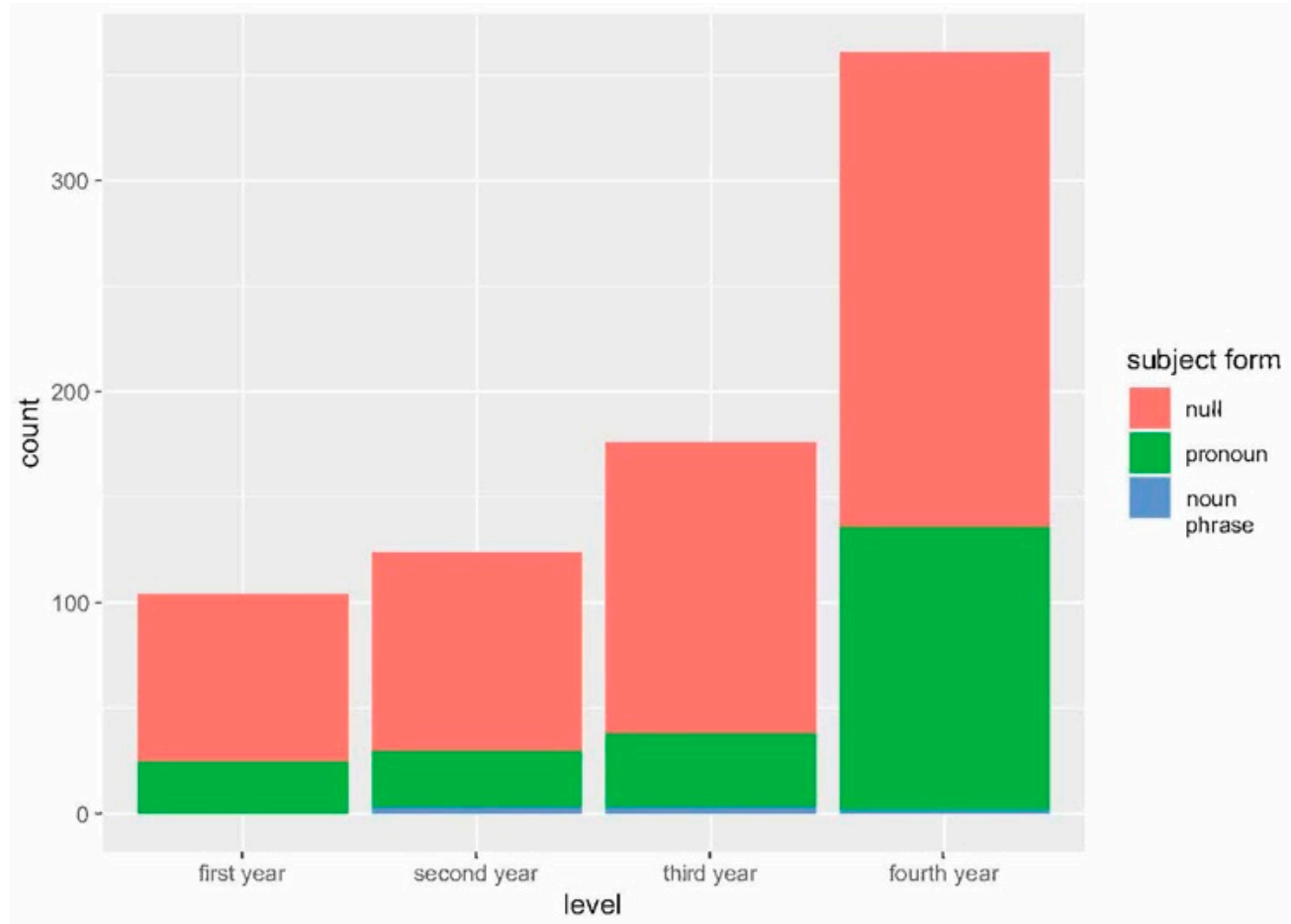

Figure 1. Distribution of subject forms by course level.

\subsection{Constraints on Subject Form Use}

Given the very low frequency of occurrence of lexical noun phrases $(n=8)$, the dataset was limited to null subjects and overt personal pronouns $(n=757)$ to examine the relationship between subject form use and each linguistic and extralinguistic factor selected for coding and analysis (see Section 3.3). As a reminder, mixed modeling was used to assess the effect of linguistic and extralinguistic factors (i.e., fixed effects) on subject-form use while accounting for hierarchical groupings in the data (i.e., random effects). The fixed effects from the minimal adequate generalized linear mixed model are shown in Table 6 (see Appendix A for a summary of random effects).

The minimal adequate model provided a better fit for the data than a reduced model that included no fixed effects $\left(\chi^{2}[9]=32.93, p<0.001\right)$. Table 6 shows that four factors were statistically significant predictors of the use of an overt personal pronoun (over a null subject): verb number, verb semantics, verb-form regularity, and use of Spanish outside of class. Switch reference, priming, course level, speaker gender, and previous study abroad experience were not statistically significant predictors of overt personal pronoun use. Learners were significantly more likely to produce an overt personal pronoun with singular as opposed to plural verbs (see Figure 2). Learners were also significantly more likely to produce an overt personal pronoun with irregular verbs as opposed to formspecific verbs (see Figure 3), and learners who reported never using Spanish outside of class were more likely to produce an overt personal pronoun than learners who reported using Spanish outside of class daily (see Figure 4). Lastly, learners were significantly less likely to use an overt personal pronoun with a mental activity verb as opposed to an external activity verb (see Figure 5). 
Table 6. Fixed effects of mixed model predicting use of an overt personal pronoun.

\begin{tabular}{lccc}
\hline \multicolumn{1}{c}{ Fixed Effect } & Estimate & z Value & $p$ Value \\
\hline (Intercept) & -5.36 & -5.44 & $5.22 \mathrm{e}-08$ \\
Verb number & & & \\
Plural & reference level & & \\
Singular & $\mathbf{2 . 6 2}$ & $\mathbf{3 . 2 6}$ & $\mathbf{0 . 0 0 1}$ \\
Verb semantics & & & \\
External activity & reference level & $-\mathbf{2 . 5 5}$ & $\mathbf{0 . 0 1 1}$ \\
Mental activity & $-\mathbf{1 . 1 6}$ & -0.23 & 0.821 \\
Stative & -0.08 & & \\
Verb-form regularity & & & \\
Form specific & reference level & $\mathbf{2 . 4 3}$ & $\mathbf{0 . 0 1 5}$ \\
Irregular & $\mathbf{0 . 8 5}$ & 1.18 & 0.237 \\
Regular & 0.40 & & \\
Spanish use outside of class & & & \\
Daily & reference level & 1.87 & 0.062 \\
Weekly & 1.21 & 1.09 & 0.275 \\
Monthly & 1.42 & $\mathbf{2 . 0 2}$ & 0.618 \\
Yearly & -0.82 & $\mathbf{0 . 0 4 3}$ \\
Never & $\mathbf{1 . 8 2}$ & & \\
\hline
\end{tabular}

Note: The model fit the log-odds of overt personal pronouns. Speaker and verb were included as random intercepts (speaker: $\sigma^{2}=2.67, S D=1.63$; verb: $\sigma^{2}=0.22, S D=0.47$ ).

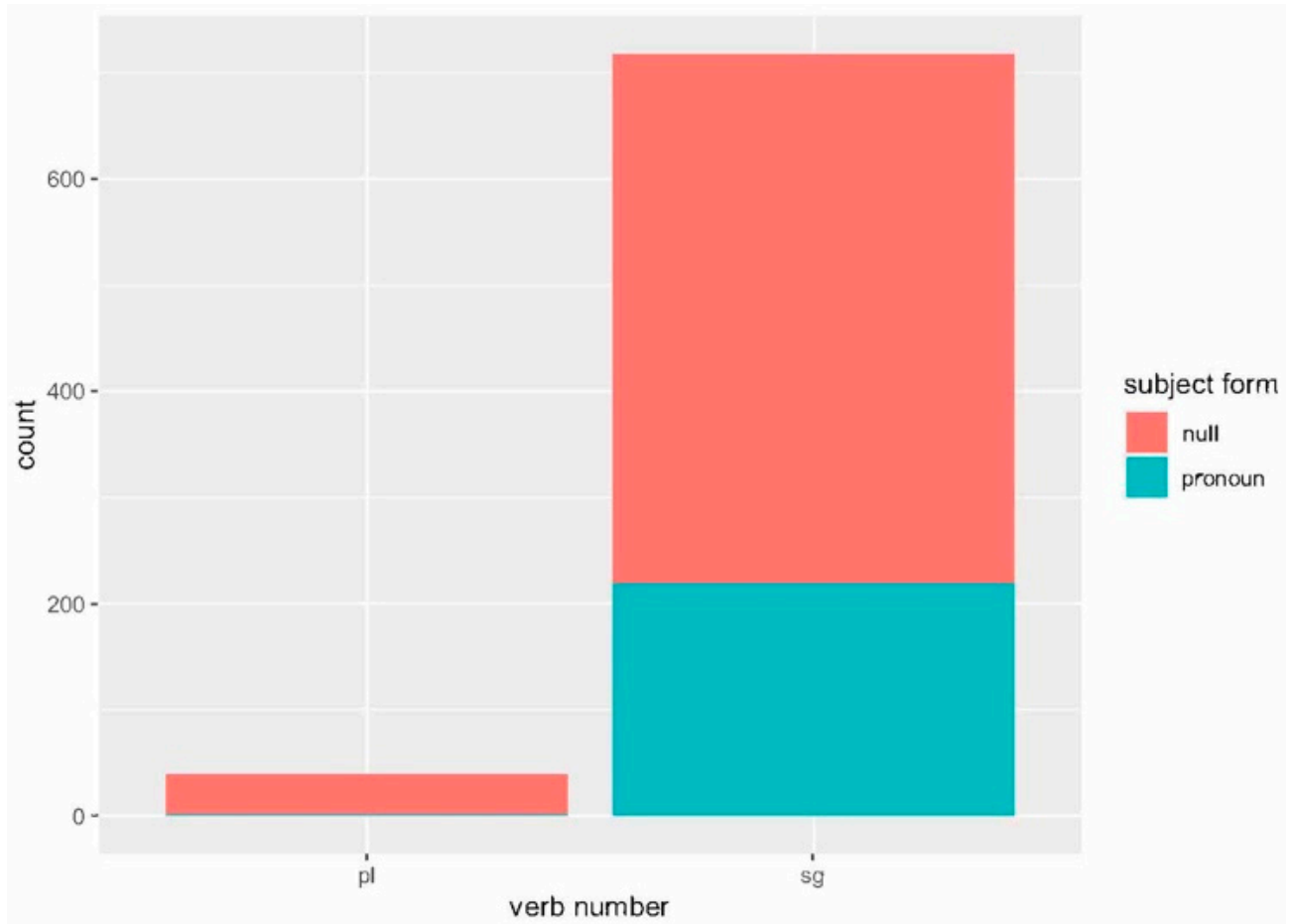

Figure 2. Visual plot of the relationship between subject-form use and verb number. 


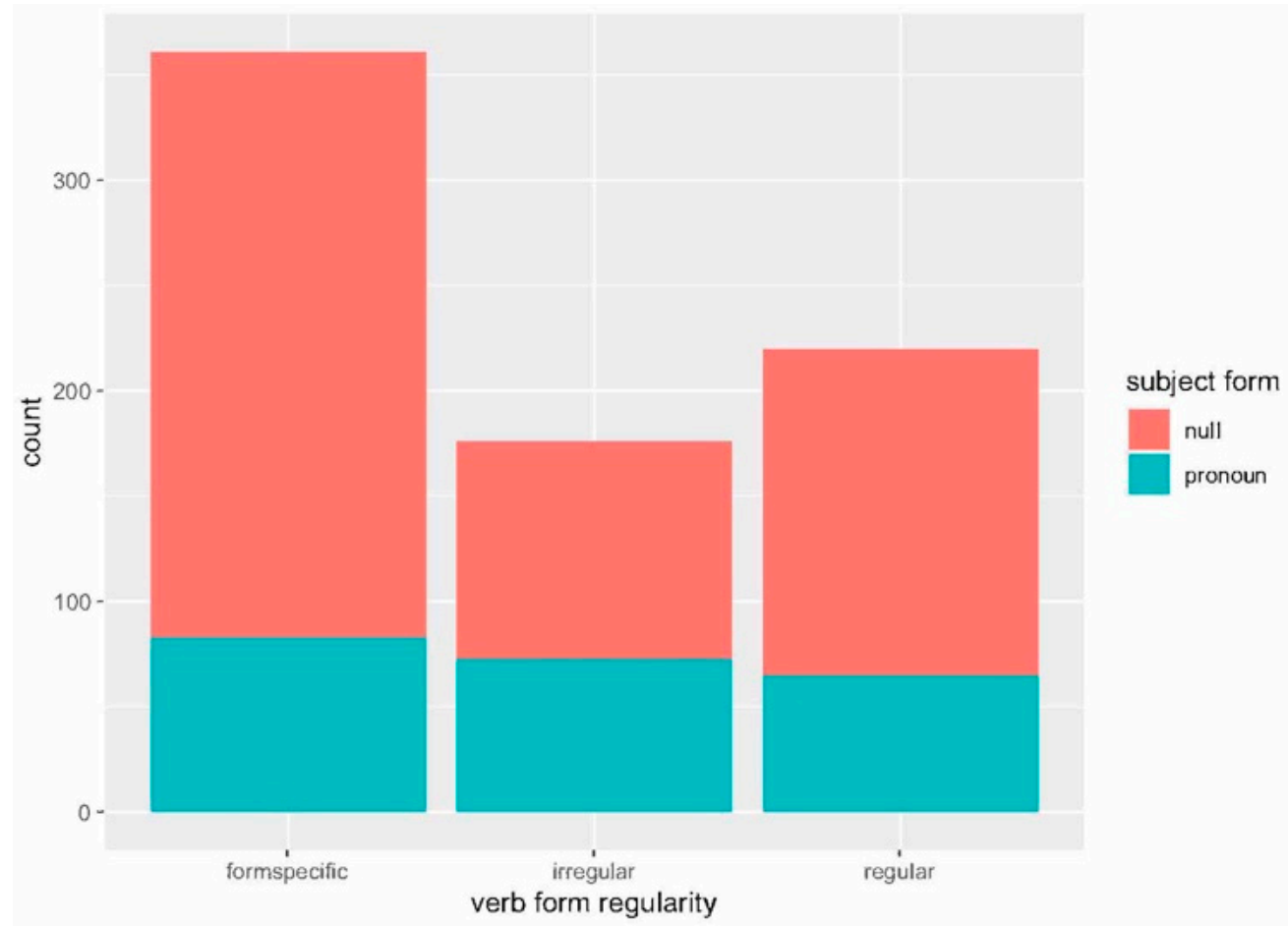

Figure 3. Visual plot of the relationship between subject-form use and verb-form regularity.

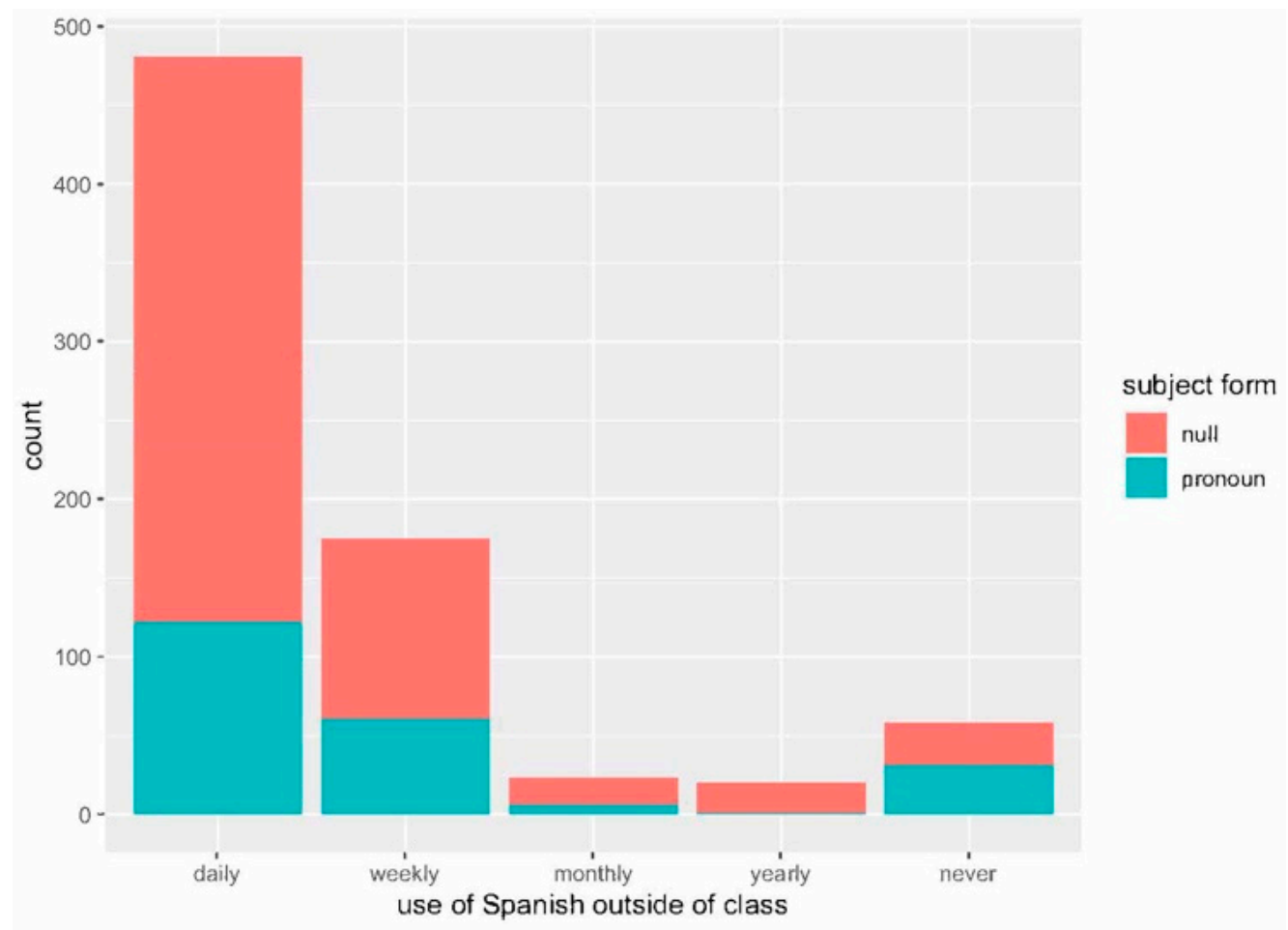

Figure 4. Visual plot of the relationship between subject-form use and use of Spanish outside of class. 


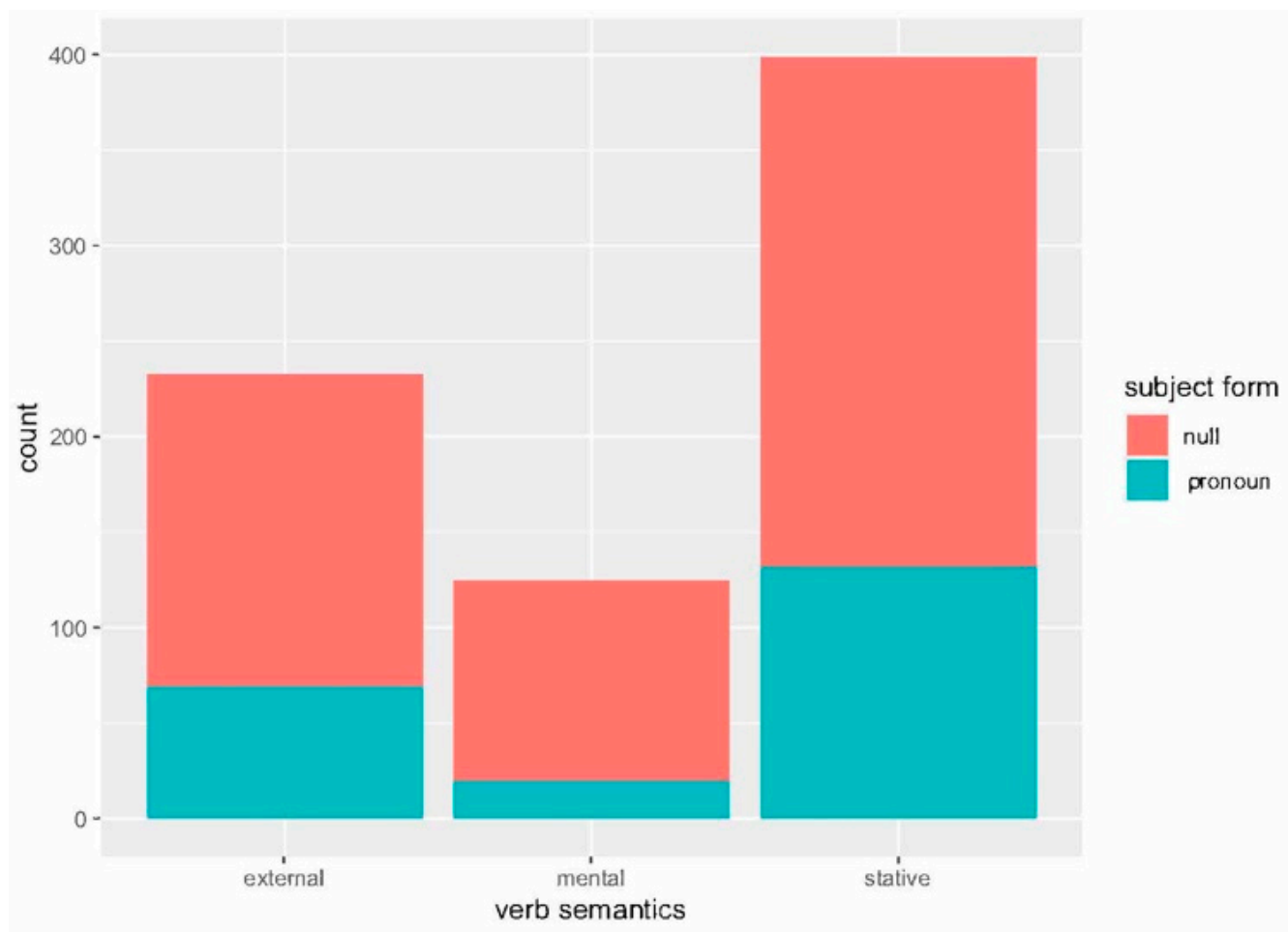

Figure 5. Visual plot of the relationship between subject-form use and verb semantics.

\section{Discussion}

This section begins with a summary of the findings for each research question guiding the present study as well as their connection to previous research. The first research question addressed the subject forms produced in first-person contexts with tensed verbs in Spanish by Korean-speaking learners during an interview task. Findings from the present study showed that Korean-speaking learners produced the full range of subject forms attested for native speakers and English-speaking learners in the existing literature (e.g., Geeslin and Gudmestad 2008b, 2011; Gudmestad and Geeslin 2010; Linford 2009)_that is, null subjects, overt personal pronouns, and lexical noun phrases (for first-person-plural referents). The second research question addressed the frequency with which each subject form was used, as well as how form frequencies changed across four instructional levels representing increasing experience with the Spanish language. Null subjects represented the most frequent subject form produced by Korean-speaking learners, followed by overt personal pronouns, and then lexical noun phrases. As instructional level increased, the rate of use of null subjects decreased gradually while overt personal pronoun use increased. These findings show more similarities than differences with previous research on Englishspeaking learners. Similarly to English-speaking learners (e.g., Geeslin and Gudmestad 2008b, 2011; Gudmestad and Geeslin 2010; Linford 2009), null subjects are the most frequent form used by Korean-speaking learners. Moreover, null subjects were used much more frequently than overt personal pronouns in first-person-singular contexts, and this pattern has been previously reported for English-speaking learners (Geeslin and Gudmestad 2016). The developmental pattern uncovered in the present study represents an important difference from previous research on English-speaking learners (e.g., Geeslin et al. 2015; Linford 2009), which has reported an increase in the use of null subjects as proficiency increases, as well as a tendency to overshoot rates reported or found for native speakers.

The implication of these findings thus far is that, in extending research on Spanish subject expression to learners of distinct first-language backgrounds, we may expect the same range of subject forms attested for native English-speaking learners to generalize to different learner populations. This could be the case because classroom learners receive explicit instruction on subject forms; however, it may also be related to similarities in the range of possible forms available for subject expression crosslinguistically. To illustrate, 
Korean-speaking learners of Spanish produce non-target-like copula forms that are not observed for English-speaking learners (Geeslin and Long 2015; Long 2021a), a finding that has been connected to differences in the way attribution is expressed in Korean and Spanish. However, subject expression shares more similarities than differences with respect to the range of possible forms occupying the subject position (e.g., pronouns, nouns and noun phrases, expletives, etc.) in Korean and Spanish; therefore, the possible range of forms used to express subjects is relatively limited when compared with other variable morphosyntactic phenomena (e.g., copula use). That stated, future research should endeavor to examine learners from typologically distinct first-language backgrounds to corroborate or revise this prediction.

The third research question sought to identify linguistic and extralinguistic predictors of subject expression in first-person contexts for Korean-speaking learners. It will be recalled that several of the same linguistic factors examined in previous research with native speakers and English-speaking learners were selected for analysis. Additionally, the individual or extralinguistic factors selected for analysis were motivated by previous L2 Spanish variation research that has examined the role of the same individual characteristics examined in the present study. With respect to the linguistic factors examined, three were found to significantly predict use of an overt personal pronoun over a null subject for Korean-speaking learners in the present study: verb number, verb-form regularity, and verb semantics. Learners were significantly more likely to use an overt personal pronoun with singular (as opposed to plural) verbs and with irregular (as opposed to form-specific) verbs. Learners were significantly less likely, on the other hand, to use an overt personal pronoun with mental activity (as opposed to external activity) verbs. In comparing these findings to previous research, similarly to English-speaking learners (Linford 2009), the verb number factor was a significant predictor of overt subject-pronoun use for Koreanspeaking learners. However, unlike the English-speaking learners in Linford's study, the switch reference factor was not a significant predictor for the Korean-speaking learners. Although a direct comparison between studies is not possible, these findings tentatively support the observation that morphosyntactic constraints may be acquired earlier than discourse constraints, and this may apply broadly to learner groups regardless of firstlanguage background. Of course, future research with more advanced Korean-speaking learners and other learner groups is needed to assess this prediction. Future research should also examine patterns of subject-form use in third-person contexts given differences in use attested by verb person and number (see Gudmestad et al. 2013).

With respect to the individual or extralinguistic factors examined, use of Spanish outside of class was the only significant predictor of overt personal pronoun use for the Korean-speaking learners in this study. Specifically, learners who reported never using Spanish outside of class were significantly more likely to use an overt personal pronoun during the interview than learners who reported using Spanish outside of class daily. Fixed effects related to experience outside of the classroom have been examined to some extent in relation to the development and use of variable morphosyntactic phenomena (see, e.g., Geeslin and Guijarro-Fuentes (2005) or Long (2021b) for research on the role of learner characteristics in Spanish copula choice), and these studies point to a positive relationship between native-like patterns of use and certain individual characteristics. However, Gudmestad and Edmonds (n.d.) reported no impact of engagement with Spanish on first-person subject use for learners who had studied abroad. For the present study, the relationship between first-person subjects and use of Spanish outside of class is somewhat unexpected (i.e., learners who reported never using Spanish outside of class might be expected to use more null subjects). Taken together, more research on this factor is needed to better understand its influence on L2 Spanish subject expression development and use. Because more linguistic factors than individual characteristics predicted subject-form use, it may be that the Korean-speaking learners in this study are still at a much earlier stage than English-speaking learners with respect to development of subject expression. It may also be that, similarly to what has been reported for other variable morphosyntactic phenomena 
(e.g., Geeslin 2003), linguistic factors are better predictors than social or extralinguistic factors for learners or non-native speakers (Geeslin 2011). Again, future research with advanced Korean-speaking learners is needed to assess more comprehensively the effect of individual characteristics on variable Spanish subject expression.

\section{Conclusions}

The present study examined the development of variable subject expression in Spanish by native Korean-speaking learners. Perhaps the most important contribution of this study to the existing literature on variable morphosyntactic phenomena in L2s is its focus on non-English-speaking learners whose first language is typologically distinct from Spanish. In this way, the generalizability of current findings can be explored, and we can begin to identify similarities in, and investigate with greater understanding the development of, variation in Spanish as an L2. Because the learner population examined in the present study remains relatively understudied, much additional work is needed. Future research focusing on Korean-speaking learners should investigate the role of additional linguistic factors known to constrain subject expression in Spanish (e.g., verb TMA) and examine linguistic behavior across different task types (e.g., written contextualized preference task; Geeslin et al. 2015). Additionally, knowledge of English and other languages should be examined to determine the extent to which patterns of use are mediated by knowledge of additional languages (see, e.g., Geeslin and Guijarro-Fuentes 2005).

Funding: This research received no external funding.

Institutional Review Board Statement: The study was approved by the Institutional Review Board of Indiana University (protocol number 1303010851; approval date 16 May 2014).

Informed Consent Statement: Informed consent was obtained from all subjects involved in the study.

Acknowledgments: I am very grateful for the feedback of the reviewers and the editor, whose comments and suggestions helped improve this manuscript. All remaining errors are my own.

Conflicts of Interest: The authors declare no conflict of interest.

\section{Appendix A}

Table A1. Random effects of mixed model predicting use of an overt personal pronoun.

\begin{tabular}{ccc}
\hline Group & Variance & $S D$ \\
\hline Speaker & 2.67 & 1.63 \\
Verb & 0.22 & 0.47 \\
\hline
\end{tabular}

Note: Number of observations $=757$.

\section{Notes}

1 Extralinguistic or social factors such as age, gender, education, socioeconomic status, and language contact have been examined alongside several of the linguistic factors outlined in Table 1.

2 Previous research that has examined the role of individual characteristics in patterns of use of a variable Spanish morphosyntactic phenomenon has focused on copula choice (Geeslin and Guijarro-Fuentes 2005; Long 2021b).

\section{References}

Abreu, Laurel. 2009. Spanish Subject Personal Pronoun Use by Monolinguals, Bilinguals and Second Language Learners. Ph.D. dissertation, University of Florida, Gainesville, FL, USA.

Abreu, Laurel. 2012. Subject pronoun expression and priming effects among bilingual speakers of Puerto Rican Spanish. In Selected Proceedings of the 14th Hispanic Linguistics Symposium. Edited by Kimberly Geeslin and Manuel Díaz-Campos. Somerville: Cascadilla Proceedings Project, pp. 1-8.

Ahn, Hyun-Jung, and Yeon-Jin Kwon. 2012. A study of topic prominence in Korean. Inmwunkwahakyenkwu 33: 81-101.

Al-Kasey, Tamara, and Ana Teresa Pérez-Leroux. 1998. Second language acquisition of Spanish null subjects. In The Generative Study of Second Language Acquisition. Edited by Suzanne Flynn, Gita Martohardjono and Wayne O’Neil. Hillsdale: Lawrence Erlbaum, pp. 161-83. 
Ávila-Jiménez, Barbara I. 1995. A sociolinguistic analysis of a change in progress: Pronominal overtness in Puerto Rican Spanish. Cornell Working Papers in Linguistics 13: 25-48.

Bates, Douglas, Martin Maechler, Benjamin M. Bolker, and Steven C. Walker. 2015. Fitting linear mixed-effects models using lme4. Journal of Statistical Software 67: 1-48. [CrossRef]

Bayley, Robert, and Dennis R. Preston, eds. 1996. Second Language Acquisition and Linguistic Variation. Amsterdam: John Benjamins Publishing.

Bayley, Robert, Kristen Greer, and Cory Holland. 2013. Lexical frequency and syntactic variation: A test of a linguistic hypothesis. University of Pennsylvania Working Papers in Linguistics 19: 21-30.

Bayley, Robert, and Lucinda Pease-Álvarez. 1997. Null pronoun variation in Mexican-descent children's narrative discourse. Language Variation and Change 9: 349-71. [CrossRef]

Blackwell, Sarah E., and Margaret Lubbers Quesada. 2012. Third-person subjects in native speakers' and L2 learners' narratives: Testing (and revising) the Givenness Hierarchy for Spanish. In Selected Proceedings of the 14th Hispanic Linguistics Symposium. Edited by Kimberly Geeslin and Manuel Díaz-Campos. Somerville: Cascadilla Proceedings Project, pp. 142-64.

Cameron, Richard. 1992. Pronominal and Null Subject Variation in Spanish: Constraints, Dialects, and Functional Compensation. Ph.D. dissertation, University of Pennsylvania, Philadelphia, PA, USA.

Cameron, Richard. 1993. Ambiguous agreement, functional compensation, and nonspecific tú in the Spanish of San Juan, Puerto Rico and Madrid, Spain. Language Variation and Change 5: 305-34. [CrossRef]

Cameron, Richard. 1994. Switch reference, verb class and priming in a variable syntax. In Papers from the 30th Regional Meeting of the Chicago Linguistics Society: Parasession on Variation in Linguistic Theory. Edited by Katharine P. Beals. Chicago: Chicago Linguistics Society, pp. 27-45.

Cameron, Richard, and Nydia Flores-Ferrán. 2004. Perseveration of subject expression across regional dialects of Spanish. Spanish in Context 1: 41-65. [CrossRef]

Canale, Michael, and Merrill Swain. 1980. Theoretical bases of communicative approaches to second language teaching and testing. Applied Linguistics 1: 1-47. [CrossRef]

Carvalho, Ana M., Rafael Orozco, and Naomi L. Shin, eds. 2015. Subject Pronoun Expression in Spanish: A Cross-dialectal Perspective. Washington, DC: Georgetown University Press.

de Prada Pérez, Ana. 2015. First person singular subject pronoun expression in Spanish in contact with Catalan. In Subject Pronoun Expression in Spanish: A Cross-Dialectal Perspective. Edited by Ana M. Carvalho, Rafael Orozco and Naomi Lapidus Shin. Washington, DC: Georgetown University Press, pp. 121-42.

Dumont, Jenny. 2006. Full NPs as subjects. In Selected Proceedings of the 9th Hispanic Linguistics Symposium. Edited by Nuria Sagarra and Almeida Jacqueline Toribio. Somerville: Cascadilla Press, pp. 286-96.

Enríquez, Emilia V. 1984. El Pronombre Personal Sujeto en la Lengua Española Hablada en Madrid. Madrid: Consejo Superior de Investigaciones Científicas.

Erker, Daniel, and Gregory R. Guy. 2012. The role of lexical frequency in syntactic variability: Variable subject personal pronoun expression in Spanish. Language 88: 526-57. [CrossRef]

Flores-Ferrán, Nydia. 2002. Subject Personal Pronouns in Spanish Narratives of Puerto Ricans in New York City: A Sociolinguistic Perspective. München: Lincom Europa.

Flores-Ferrán, Nydia. 2004. Spanish subject personal pronoun use in New York City Puerto Ricans: Can we rest the case of English contact? Language Variation and Change 16: 49-73. [CrossRef]

Geeslin, Kimberly L. 2003. A comparison of copula choice: Native Spanish speakers and advanced learners. Language Learning 53: 703-64. [CrossRef]

Geeslin, Kimberly L. 2011. Variation in L2 Spanish: The state of the discipline. Studies in Hispanic and Lusophone Linguistics 4: 461-518. [CrossRef]

Geeslin, Kimberly L., and Aarnes Gudmestad. 2008a. Comparing interview and written elicitation tasks in native and non-native data: Do speakers do what we think they do? In Selected Proceedings of the 10th Hispanic Linguistics Symposium. Edited by Joyce Bruhn de Garavito and Elena Valenzuela. Somerville: Cascadilla Proceedings Project, pp. 64-77.

Geeslin, Kimberly L., and Aarnes Gudmestad. 2008b. Variable subject expression in second-language Spanish: A comparison of native and non-native speakers. In Selected Proceedings of the 2007 Second Language Research Forum. Edited by Melissa Bowles, Rebecca Foote, Silvia Perpiñán and Rakesh Mohan Bhatt. Somerville: Cascadilla Proceedings Project, pp. 69-85.

Geeslin, Kimberly L., and Aarnes Gudmestad. 2016. Subject expression in Spanish: Contrasts between native and non-native speakers for first and second-person singular referents. Spanish in Context 13: 53-79. [CrossRef]

Geeslin, Kimberly, and Aarnes Gudmestad. 2011. Using sociolinguistic analyses of discourse-level features to expand research on L2 variation in forms of Spanish subject expression. In Selected Proceedings of the 2009 Second Language Research Forum. Edited by Luke Plonsky and Maren Schierloh. Somerville: Cascadilla Proceedings Project, pp. 16-30.

Geeslin, Kimberly L., and Avizia Y. Long. 2014. Sociolinguistics and Second Language Acquisition: Learning to use Language in Context. New York: Routledge.

Geeslin, Kimberly L., and Avizia Y. Long. 2015. The development and use of the Spanish copula with adjectives by Korean-speaking learners. In New Perspectives on the Study of Ser and Estar. Edited by Isabel Pérez-Jiménez, Manuel Leonetti and Silvia GumielMolina. Amsterdam: John Benjamins, pp. 293-324. 
Geeslin, Kimberly, Bret Linford, and Stephen Fafulas. 2015. Variable subject expression in second language Spanish: Uncovering the developmental sequence and predictive linguistic factors. In Subject Pronoun Expression in Spanish: A Cross-dialectal Perspective. Edited by Ana Carvalho, Rafael Orozco and Naomi L. Shin. Washington, DC: Georgetown University Press, pp. $220-41$.

Geeslin, Kimberly, and Pedro Guijarro-Fuentes. 2005. The acquisition of copula choice in instructed Spanish: The role of individual characteristics. In Studies in the Acquisition of the Hispanic Languages: Papers from the 6th Conference on the Acquisition of Spanish and Portuguese as First and Second Languages. Edited by David Eddington. Somerville: Cascadilla Press, pp. 66-77.

Gudmestad, Aarnes. 2012. Acquiring a variable structure: An interlanguage analysis of second-language mood use in Spanish. Language Learning 62: 373-402. [CrossRef]

Gudmestad, Aarnes, and Amanda Edmonds. n.d. The variable use of first-person-singular subject forms during an academic year abroad. In Study Abroad and the Second Language Acquisition of Sociolinguistic Variation in Spanish. Edited by Sara Zahler, Avizia Long and Bret Linford. Amsterdam: John Benjamins.

Gudmestad, Aarnes, and Kimberly L. Geeslin. 2010. Exploring the roles of redundancy and ambiguity in variable subject expression: A comparison of native and non-native speakers. In Selected Proceedings of the 12th Hispanic Linguistics Symposium. Edited by Claudia Borgonovo, Manuel Español-Echevarría and Philippe Prévost. Somerville: Cascadilla Proceedings Project, pp. $270-83$.

Gudmestad, Aarnes, and Kimberly L. Geeslin. 2021. Overlapping envelopes of variation: The case of lexical noun phrases and subject expression in Spanish. In The Routledge Handbook of Variationist Approaches to Spanish. Edited by Manual Díaz-Campos. New York: Routledge, pp. 437-49.

Gudmestad, Aarnes, Leanna House, and Kimberly L. Geeslin. 2013. What a Bayesian analysis can do for SLA: New tools for the sociolinguistic study of subject expression in L2 Spanish. Language Learning 63: 371-99. [CrossRef]

Hochberg, Judith G. 1986. Functional compensation for /-s/ deletion in Puerto Rican Spanish. Language 62: 609-21. [CrossRef]

Holmquist, Jonathan. 2012. Frequency rates and constraints on subject personal pronoun expression: Findings from the Puerto Rican highlands. Language Variation and Change 24: 203-20. [CrossRef]

Huang, C. T. James. 1984. On the distribution and reference of empty pronouns. Linguistic Inquiry 15: 531-74.

Huang, C. T. James. 1989. Pro-drop in Chinese: A generalized control theory. In The Null Subject Parameter. Edited by Osvaldo Jaeggli and Kenneth J. Safir. Dordrecht: Kluwer Academic Publishers, pp. 185-214.

Im, Hong-Pin. 1985. Kwukeuy 'thongsacekin' kongpemcwuey tayhaye [On 'syntactic' empty categories in Korean]. Ehakyenkwu 21: 331-84.

Isabelli, Casilde A. 2004. The acquisition of the null subject parameter properties in SLA: Some effects of positive evidence in a naturalistic learning context. Hispania 87: 150-62. [CrossRef]

Kim, Young-Joo. 2000. Subject/object drop in the acquisition of Korean: A cross-linguistic comparison. Journal of East Asian Linguistics 9: 325-51. [CrossRef]

Labov, William. 1972. Sociolinguistic Patterns. Philadelphia: University of Pennsylvania Press.

Lee, Hong Bae. 1993. Theories of the null subject parameter and Korean. Ene [Korean Journal of Linguistics] 18: 331-61.

Lee, Narah. 2019. A Pragmatic and Sociocultural Perspective to Subject Expression in Spoken Korean: With Focus on First and Second Person. Ph.D. dissertation, The Australian National University, Canberra, ACT, Australia.

Liceras, Juana M., and Lourdes Díaz. 1998. On the nature of the relationship between morphology and syntax: Inflectional typology, f-Features and null/overt pronouns in Spanish interlanguage. Language Acquisition and Language Disorders 19: 307-38.

Liceras, Juana M., and Lourdes Díaz. 1999. Topic-drop versus pro-drop: Null subjects and pronominal subjects in the Spanish L2 of Chinese, English, French, German and Japanese speakers. Second Language Research 15: 1-40. [CrossRef]

Linford, Bret. 2009. The Acquisition of Subject Pronouns in Second Language Spanish. Master's thesis, The University of Montana, Missoula, MT, USA.

Linford, Bret. 2012. Self-reported motivation and the L2 acquisition of subject pronoun variation in Spanish. In Selected Proceedings of the 2012 Second Language Research Forum. Edited by Ryan T. Miller, Katherine I. Martin, Chelsea M. Eddington, Ashlie Henery, Nausica Marcos Miguel, Alison M. Tseng, Alba Tuninetti and Daniel Walter. Somerville: Cascadilla Proceedings Project, pp. $193-210$.

Long, Avizia Y. 2016. The Acquisition of Sociolinguistic Competence by Korean Learners of Spanish: Development and Use of the Copula, Subject Expression, and Intervocalic Stops. Ph.D. dissertation, Indiana University, Bloomington, IN, USA.

Long, Avizia Y. 2021a. Classroom learners' acquisition of the Spanish copula with adjectives: The case of Korean learners. Studies in Second Language Acquisition, 1-27. [CrossRef]

Long, Avizia Y. 2021b. The role of individual characteristics in the acquisition of Spanish copula choice. In Advancedness in Second Language Spanish: Definitions, Challenges, and Possibilities. Edited by Mandy Menke and Paul Malovrh. Amsterdam: John Benjamins, pp. 417-40.

Long, Avizia Y., and Kimberly Geeslin. 2018. Spanish second language acquisition across the globe: What future research on non-English speaking learners will tell us. Hispania 100: 205-10. [CrossRef]

Lozano, Cristóbal. 2002a. Knowledge of expletive and pronominal subjects by learners of Spanish. ITL Review of Applied Linguistics 135: 37-60. [CrossRef]

Lozano, Cristóbal. 2002b. The interpretation of overt and null pronouns in non-native Spanish. Durham Working Papers in Linguistics 8: 53-66.

Martínez-Sanz, Cristina. 2011. Null and Overt Subjects in a Variable System: The Case of Dominican Spanish. Ph.D. dissertation, University of Ottawa, Ottawa, ON, Canada. 
Moon, Gui-Sun. 2010. Null arguments redux. Ene [Korean Journal of Linguistics] 18: 67-92.

Morales, Amparo. 1986. Gramáticas en Contacto: Análisis Sintácticos Sobre el Español de Puerto Rico. Puerto Rico/Madrid: Editorial Playor.

$\mathrm{Na}$, Chae Woon. 1988. Wulimaluy thukcingey kwanhan han kochal: Inching, hoching, cichingey kwanhan oykwukewauy pikyokochalul cwungsimulo [A study of the characteristics of Korean: Focusing on person reference, address terms and reference terms]. Cangsinnontan [Korea Presbyterian Journal of Theology], 36-65.

Otheguy, Ricardo, and Ana Celia Zentella. 2012. Spanish in New York: Language Contact, Dialectal Leveling, and Structural Continuity. Oxford: Oxford University Press.

Otheguy, Ricardo, Ana Celia Zentella, and David Livert. 2007. Language and dialect contact in Spanish in New York: Toward the formation of a speech community. Language 83: 770-802. [CrossRef]

Pérez-Leroux, Ana Teresa, and William R. Glass. 1997. OPC effects on the L2 acquisition of Spanish. Contemporary Perspectives on the Acquisition of Spanish 1: 149-65.

Pérez-Leroux, Ana Teresa, and William R. Glass. 1999. Null anaphora in Spanish second language acquisition: Probabilistic versus generative approaches. Second Language Research 15: 220-49. [CrossRef]

Posio, Pekka. 2011. Spanish subject pronoun usage and verb semantics revisited: First and second person singular subject pronouns and focusing of attention in spoken Peninsular Spanish. Journal of Pragmatics 43: 777-98. [CrossRef]

Quesada, Margaret Lubbers, and Sarah E. Blackwell. 2009. The L2 acquisition of null and overt Spanish subject pronouns: A pragmatic approach. In Selected Proceedings of the 11th Hispanic Linguistics Symposium. Edited by Joseph Collentine, Maryellen García, Barbara Lafford and Francisco Marcos Marín. Somerville: Cascadilla Proceedings Project, pp. 117-30.

R Core Team. 2019. R. A Language and Environment for Statistical Computing. Vienna: R Foundation for Statistical Computing. Available online: http:/ / www.r-project.org/ (accessed on 3 December 2021).

Regan, Vera, and Robert Bayley. 2004. Introduction: The acquisition of sociolinguistic competence. Journal of Sociolinguistics 8: 323-38.

Rothman, Jason, and Michael Iverson. 2007a. Input type and parameter resetting: Is naturalistic input necessary? International Review of Applied Linguistics 45: 285-319. [CrossRef]

Rothman, Jason, and Michael Iverson. 2007b. On parameter clustering and resetting the null- subject parameter in L2 Spanish: Implications and observations. Hispania 90: 328-41.

Rothman, Jason, and Michael Iverson. 2007c. The syntax of null subjects in L2 Spanish: Comparing two L2 populations under different exposure. Revista Española de Lingüística Aplicada 20: 185-214.

Shin, Naomi L., and Ricardo Otheguy. 2009. Shifting sensitivity to continuity of reference: Subject pronoun use in Spanish in New York City. In Español en Estados Unidos y en Otros Contextos: Cuestiones Sociolingüísticas, Políticas y Pedagógicas. Edited by Manel Lacorte and Jennifer Leeman. Madrid: Iberoamericana, pp. 111-36.

Silva-Corvalán, Carmen. 1982. Subject Expression and Placement in Mexican-American Spanish. Cambridge: Cambridge University Press.

Sohn, Ho-Min. 1999. The Korean language. Cambridge: Cambridge University Press.

Tagliamonte, Sali A. 2012. Variationist Sociolinguistics: Change, Observation, Interpretation. Hoboken: John Wiley \& Sons.

Torres Cacoullos, Rena, and Catherine Travis. 2010. Variable yo expression in New Mexico: English infuence? In Spanish of the U.S. Southwest: A Language in Transition. Edited by Susana Rivera-Mills and Daniel Villa Crésap. Madrid: Iberoamericana/Vervuert, pp. 189-210.

Travis, Catherine E. 2005. The yo-yo effect: Priming in subject expression in Colombian Spanish. In Theoretical and Experimental Approaches to Romance Linguistics. Edited by Randall S. Gess and Edward J. Rubin. Amsterdam: John Benjamins, pp. 329-49.

Travis, Catherine E. 2007. Genre effects on subject expression in Spanish: Priming in narrative and conversation. Language Variation and Change 19: 101-35. [CrossRef] 